Vol. 2, No. 1, Januari - Juni 2018

\title{
edureligia
}

\section{ANALISA MATERI PELAJARAN SEJARAH KEBUDAYAAN ISLAM MADRASAH ALIYAH KELAS XI DAN RELEVANSINYA DI INDONESIA}

\section{Siti Masulah ${ }^{1}$}

Sekolah Tinggi Ilmu Ekonomi Syariah Nahdlatul Ulama Bengkulu

\section{Info Artikel}

Sejarah Artikel:

Diterima; Desember 2017

Disetujui; Januari 2018

Dipublikasikan; Maret

2018

Keywords:

Hermeneutics; islamic

cultural history; the plurality

of nations

\begin{abstract}
One part of the subjects of national education is Islamic education. As for the grouping of Islamic teachings in the form of subjects in Madrasah ranging from Madrasah Ibtidaiyah (MI), Madrasah Tsanawiyah (MTs), and Madrasah Aliyah (MA), there are subjects devoted to religious specialization. At the level of Madrasah Aliyah (MA), the specialization of the Religious sciences was developed in the form of study-specific subjects and there were also subjects that served as supporters such as the subjects of Islamic Cultural History. In this paper, the author analyzes the student manual for the subjects of Islamic Culture History class XI (Scientific Approach Curriculum 2013) using an analytical study approach in terms of the order of subject matter in the book and the double movement hermeneutics study approach ala Fazlur Rahman. The results of this study explain that the SKI subjects have been elaborated with clear and detailed indicators, but the subject matter of the SKI has not provided an analysis description for the development of scientific insights of students in answering the actual problems, for example, the plurality that characterizes the Indonesian nation. Therefore, the SKI study must involve Fazlur Rahman's hermeneutic analysis and Nietzsche's critical history analysis to read past phenomena to build on current progress in accordance with the mandate of National Education System Law No. 20 of 2003.
\end{abstract}

Email :sitimasulah74319@mail.com 


\section{PENDAHULUAN}

Sebagai negara yang paling majemuk baik dari segi sosio-kultural maupun geografis, Indonesia menjadi dapat menjadi contoh ideal dalam membangun pluralitas hidup bangsa. Sekarang ini, jumlah pulau di Negara Kesatuan Republik Indonesia (NKRI) sekitar 13.000 pulau besar dan kecil, lebih dari 200 juta jiwa penduduk dengan 300 suku dan menggunakan hampir 200 bahasa yang berbeda. Demikian juga warganya menganut agama dan kepercayaan yang beragam. Dari cara pandang, tindakan dan wawasan setiap individu juga memiliki beragam pandangan dalam melihat fenomena sosial, budaya, ekonomi, politik dan hal-hal lainnya. Negara bangsa Indonesia terdiri atas sejumlah besar kelompok-kelompok etnis, budaya, agama dan lain-lain. Menurut Hefner, Indonesia memiliki wawasan dan tantangan pluraltas budaya lebih tampak. Dari sisi horizontal, ada kesatuan-kesatuan sosial berdasarkan perbedaan suku bangsa, agama, adat, serta perbedaan kedaerahan, sedangkan secara vertikal, ada perbedaan-perbedaan vertikal antara lapisan atas dan lapisan bawah yang cukup tajam (baca: Nasikun, 2007). Dengan kondisi demikian, negara Indonesia sangat tepat sekali menjadikan prinsip bhinneka tunggal ika dalam tata kehidupan plural dari berbagai seginya (Sapendi, ).

Sebagai bagian dari kegiatan hidup berbangsa dan bernegara, pendidikan memiliki peran penting dalam menyiapkan sumberdaya manusia dalam menjawab realita pluralitas hidup bangsa Indonesia. Sebagai bagian dari perwujudan dari cita-cita bangsa, kegiatan pendidikan dilakukan sesuai dengan amanah Undang-Undang Sisdiknas No 20 Tahun 2003 pasal 3, yaitu "Pendidikan nasional bertujuan untuk berkembangnya potensi peserta didik agar menjadi manusia yang beriman dan bertakwa kepada Tuhan Yang Maha Esa, berakhlak mulia, sehat, berilmu, cakap, kreatif, mandiri, dan menjadi warga negara yang demokratis serta bertanggung jawab." Dengan tujuan pendidikan tersebut, pendidikan secara nasional dinyatakan berhasil jika peserta didik memiliki sikap yang beriman dan bertakwa, berakhlak mulia, sehat lahir dan batin, berilmu, cakap, kreatif, mandiri, dan menjadi warga negara yang demokratis serta bertanggung jawab. Dengan demikian, pendidikan nasional "berfungsi untuk mengembangkan kemampuan dan membentuk watak serta peradaban bangsa yang bermartabat dalam rangka mencerdaskan kehidupan bangsa." Oleh sebab itu, fungsi pendidikan secara nasional tidak hanya membentuk perkembangan peserta didik dalam bidang jasmani dan rohani tetapi juga mengembangkan pribadi, kewarganegaraan, budaya dan kebangsaan (Thalib \& Bahrun, 2014).

Salah satu bagian dari mata pelajaran dari pendidikan nasional adalah pendidikan Agama Islam yang secara substantif telah mengajarkan kesempurnaan dan berbagai panduan untuk dilaksanakan dalam kehidupan nyata sehari-hari untuk mencapai tujuan kehidupan yang penuh kedamaian dan rasa aman. Oleh karena itu pengelompokkan ajaran agama Islam di dalam bentuk mata pelajaran di lingkungan Madrasah mulai dari jenjang Madrasah Ibtidaiyah (MI), Madrasah Tsanawiyah (MTs), dan Madrasah Aliyah (MA) terdapat mata pelajaran yang dikhususkan untuk peminatan Keagamaan.

Pada tingkat Madrasah Aliyah (MA), peminatan ilmu-ilmu Keagamaan tersebut dikembangkan dalam bentuk kajian khusus mata pelajaran seperti : a). Tafsir- Ilmu Tafsir, b). Hadits- Ilmu Hadits, c). FiqihUshul Fiqih, d). Ilmu Kalam, e). Akhlak. Ada juga mata pelajaran yang berperan sebagai jendukūng dalam proses pembekalan materi tersebut misalnya mata pelajaran Sejarah Kebudayaan Islam dan juga mata pelajaran Bahasa Arab.

Mulai tahun ajaran 2014-2015 seluruh Madrasah yang berada di bawah pembinaan Kementerian Agama RI diharapkan mulai siap melaksanakan Kurikulum 2013. Hal ini pun sudah diatur dalam Peraturan Menteri Agama (PMA) tentang Kurikulum 2013 yang berisi Kerangka Dasar Kurikulum Madrasah 2013, Standar Kompetensi Lulusan (SKL), Standar Kompetensi Inti, Standar Kompetensi Dasar, Standar Proses dan Standar Penilaian.

Sebagai panduan implementasi Kurikulum 2013, maka Kementerian Agama telah menyiapkan model silabus Pembelajaran PAI di Madrasah, dengan menerbitkan buku-buku pegangan baik untuk guru maupun siswa. Buku pedoman tersebut menjadi kebutuhan pokok dalam mengimplementasikan Kurikulum 2013 di Madrasah.

Dalam makalah ini penulis mencoba untuk menganalisis buku pedoman siswa untuk mata pelajaran Sejarah Kebudayaan Islam kelas XI (Pendekatan Saintifik Kurikulum 2013). Buku yang akan di analisa adalah buku terbitan Kementerian Agama Republik Indonesia menggunakan Kurikulum 2013 kaitannya dengan relevansi kehidupan 
bangsa Indonesia yang majemuk dari berbagai seginya.

Dalam rangka mencari relevansi kajian mata pelajaran buku SKI tersebut, kajian ini menggunakan pendekatan disamping menggunakan kajian Analisis dari Segi Urutan Materi Pelajaran di dalam Buku, juga menggunakan pendekatan kajian hermeneutika double movement ala Fazlur Rahman yang menjelaskan bahwa pembacaan teks termasuk sejarah seharusnya tidak hanya dibaca apa adanya tetapi harus dibaca spiritnya melalui cara kembali pada kondisi asli lahirnya teks dan kemudian ditarik spiritnya untuk dirumuskan pesan idealnya di masa kini (Rahan, 1984).

\section{DESKRIPSI BUKU SEJARAH KEBUDAYAAN ISLAM KELAS XI MADRASAH ALIYAH}

Buku Sejarah Kebudayaan Islam yang akan di analisa adalah buku pedoman siswa untuk kelas XI Madrasah Aliyah. Buku ini diterbitkan oleh Kementerian Agama Republik Indonesia dalam rangka implementasi Kurikulum 2013. Buku ini disusun oleh M. Husain Tuanaya, Miftachul Ula, Mariyah Ulfah sebagai tim-konstributor naskah, dan ditelaah oleh Hasibullah Satrawi dan Muhtadin, yang mana keduanya baik tim penyusun dan penelaah tetap berada di bawah koordinasi Kementerian Agama (KEMENAG RI, 2015).

Sebagaimana yang disebutkan dalam kaidah Ushul Fiqih, " Ma la yatimmu al- wajib illa bihi fahuwa wajib" (suatu kewajiban tidak menjadi sempurna tanpa adanya hal lain yang menjadi pendukungnya, maka hal lain tersebut pun ikut menjadi wajib). Begitu juga dengan perintah menuntut ilmu, maka secara tidak langsung juga terkandung perintah untuk menyediakan sarana-sarana pendukungnya, semisal buku bahan ajar. Buku pedoman baik yang untuk guru maupun siswa ada baiknya disusun dengan pendekatan ilmiah (scientific approach) yang telah dilakukan dengan berbagai proses tahapan.

Dalam buku ini materi isi yang akan diajarkan di bagi menjadi dalam kurun waktu dua semester, semester 1 terdiri dari 4 bab dan semester 2 juga ada 4 bab materi pokok bahasan. Masing-masing materi pelajaran yang akan diberikan di kelas XI adalah sebagai berikut :

\section{Semester I}

Bab 1 Proses Lahirnya dan Fase-Fase Pemerintahan Bani Umayyah
1. Silsilah Khalifah Bani Umayyah 1

2. Proses Lahir dan Fase-Fase Pemerintahan Bani Umayyah 1

3. Fase-Fase Pemerintahan Bani Umayyah 1

Bab II Khalifah-Khalifah yang Terkenal dan Kebijakan Pemerintahan Bani Umayyah 1

1. 14 Khalifah Bani Umayyah 1 yang Berkuasa

2. Khalifah-Khalifah Bani Umayyah yang Terkenal

3. Kebijakan-Kebijakan Pemerintahan Bani Umayyah 1 Damaskus

Bab III Perkembangan Peradaban Bani Umayyah 1 Damaskus

1. Proses Kodifikasi Hadits Masa Khalifah Umar Bin Abdul Aziz.

2. Proses Perkembangan Ilmu Pengetahuan Masa Bani Umayyah 1

3. Peradaban yang Tumbuh pada Masa Bani Umayyah 1.

Bab IV Masa Kelemahan sampai Runtuhnya Bani Umayyah 1 Damaskus

1. Faktor-Faktor Penyebab Mundurnya Bani Umayyah 1.

2. Faktor-Faktor Pemicu Munculnya Pemberontakan.

3.slaKelebihan dan Kekurangan Bani

4. Proses Runtuhnya Bani Umayyah 1 di damaskus.

Semester H

$\mathrm{Bab} V$ Proses Lahirnya dan Fase-Fase

Pemerintahan Bani Abbasiyah

1. Proses Lahirnya Abbasiyah.

2. Fase-Fase Pemerintahan Bani Abbasiyah.

Bab VI Khalifah-Khalifah Abbasiyah yang Terkenal dan Kebijakan Pemerintahan Abbasiyah

1. Khalifah-Khalifah Abbasiyah yang Terkenal.

2. Kebijakan Khalifah Bani Abbasiyah.

$\mathrm{Bab}$ VII Proses Perkembangan Ilmu Pengetahuan Masa Bani Abbasiyah

1. Suasana Tumbuhnya Peradaban Ilmu Pengetahuan Masa Abbasiyah.

2. Bentuk Peradaban Hasil Riset dari Para Ahli dan Tokoh-Tokohnya.

3. Pusat-Pusat Peradaban Masa Bani Abbasiyah.

4. Pengaruh Peradaban Islam terhadap Dunia Barat.

Bab VIII Proses Perkembangan Ilmu Pengetahuan Masa Bani Abbasiyah

a. Faktor Penyebab Munculnya Pemberontakan Masa Abbasiyah.

b. Faktor Penyebab Runtuhnya Bani Abbasiyah. 
Pada masing-masing babnya terdapat

banyak sekali proses pembelajaran $m \bar{l} 1 \mathbb{N}$ dari pengamatan, perenungan, menghubungkan dan menalar, mengambil ibrah dan pembelajaran, hal ini dipermudah dengan adanya peta konsep untuk menambah wawasan pada masing-masing bahasan tiap semesternya. Kegiatan tersebut di akhiri dengan asah kompetensi dengan menjawab beberapa pertanyaan untuk menguji sejauh apa pemahaman siswa akan pembahasan di bab tersebut.

Peta konsep yang disajikan di buku ini adalah sebagai berikut :

\section{Semester I Bani Umayyah 1}

a. Latar belakang lahirnya.

b. Proses lahirnya.

c. Kebijakan khalifah.

d. Khalifah-khalifah yang memerintah.

e. Khalifah yang terkenal.

f. Perkembangan peradaban pengetahuan.

g. Tokoh-tokoh ilmu pengetahuan.

h. Pusat-pusat peradaban.

i. Faktor-faktor penyebab runtuhnya.

j. Proses runtuhnya.

Semester II Bani Abbasiyah

a. Latar belakang lahirnya.

b. Proses lahirnya.

c. Khalifah-khalifah yang memerintah.

d. Khalifah yang terkenal.

e. Kebijakan khalifah.

f. Perkembangan peradaban pengetahuan.

g. Tokoh-tokoh ilmu pengetahuan.

h. Pusat-pusat peradaban.

i. Pengaruh peradaban Islam terhadap dunia Barat.

j. Faktor-faktor penyebab runtuhnya.

\section{PEMBAHASAN}

\section{Kajian Analisis dari Segi Urutan Materi}

Pelajaran di dalam Buku

Untuk melakukan proses analisa tersebuit pada masing-masing bab dan materi pelajaran yang terdapat di buku SKI kelas XI ini, maka juga harus dipertimbangkan dari segi Kompetensi Dasar dan Kompetensi Inti mata pelajaran Sejarah Kebudayaan Islam yang sesuai dengan Keputusan Menteri Agama (KMA) No. 165 Tahun 2014 sudah terpenuhi atau belum. Berdasarkan uraian tersebut, berikut akan dilakukan analisis pada setiap bab dan materi dalam buku SKI kelas XI sebagai berikut:
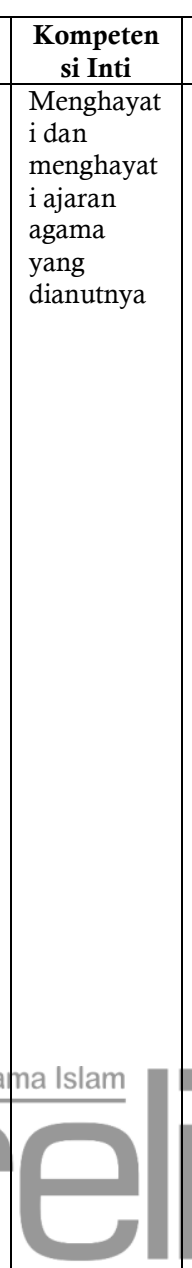
$\mathrm{mu}$ \begin{tabular}{|c|r|}
\multicolumn{3}{|c}{ Tabel 1. Semester Ganjil } \\
\hline Kompetensi
\end{tabular}

\begin{tabular}{|c|c|c|}
\hline $\begin{array}{c}\text { Kompetensi } \\
\text { Dasar }\end{array}$ & Materi & Analisa \\
\hline 1.1. Menyadari & $\mathrm{Bab} 1$ & Mate \\
\hline bahwa & Proses & yar \\
\hline kekuasaan & Lahirnya dan & disampaika \\
\hline adalah & Fase- Fa & di \\
\hline amandah dari & Pemerintaha & buku cukı \\
\hline Allah SWT & n Bani & menggam \\
\hline 7 & Umayy & kan \\
\hline $\begin{array}{l}\text { 1.2. Menyadar1 } \\
\text { dalama }\end{array}$ & 18 & tentang \\
\hline perjuangan ada & Khalifah & Bani \\
\hline fase-fase yang & Bani & Umayyah \\
\hline harus dilewati & Umayyah 1. & $\begin{array}{l}\text { di Damaskus } \\
\text { secara }\end{array}$ \\
\hline 1.3. Meyakini & 2. Pro & ringkas \\
\hline bahwa & Lahir dan & jelas \\
\hline berdakwah dan & Fase-Fas & langsung \\
\hline $\begin{array}{l}\text { melakukan hal- } \\
\text { hal vang }\end{array}$ & Pemerintaha & pada pokok \\
\hline & & \\
\hline
\end{tabular}

bermanfaat Umayyah 1.

adalah

$\begin{array}{ll}\text { kewajiban } & \text { 3. Fase-Fase }\end{array}$

setiap muslim. Pemerintaha

n Bani

bahwa ilmu a. Fase

pengetahuan berdiri,

adalah bekal pembentuka

penting bagi $\mathrm{n}$ dan

manusia untuk pembinaan.

meraih $\quad$ b. Fase

kesuksesan. kemajuan.

c. Fase

\begin{tabular}{l|l}
1.5 Menyadari & $\begin{array}{l}\text { lemah } \\
\text { bahwa }\end{array}$ \\
sampai
\end{tabular}

manusia
diciptakan oleh runtuhnya

Allah SWT

dengan

berbagai

macam potensi

sehingga

mampu

menciptakan

peradaban.

1.6 Mensyukuri

nikmat Allah

SWT berupa

kekayaan

peradaban

yang diraih

Islam

Mengemba

ngka

$\mathrm{n}$ perilaku

(jujur,

disiplin,

tanggung

jawab,

peduli,

santun,

ramah

lingkungan

, gotong

royong,

kerja sama,

cinta

damai,

responsif

dan pro-

aktif) dan
2.1

Membiasakan

sikap

bijaksana

dalam

kehidupan

sehari-hari

sebagai

inplementasi

dari

pemahaman

mengenai

proses

lahirnya

Bani

Umayyah

di

Damaskus

2.2 Meneladani
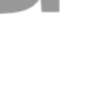

eri

eri
yang
mpaikan
bertujuan
untuk
memberik
an
gambaran
tentang
berbagai
keberhasil
an-
keberhasil
an yang
telah
dicapai
Bani
Umayyah
di




\begin{tabular}{|c|c|c|c|}
\hline $\begin{array}{l}\text { menunjukk } \\
\text { an sikap } \\
\text { sebagai } \\
\text { bagian dari } \\
\text { solusi atas } \\
\text { berbagai } \\
\text { permasala } \\
\text { han bangsa } \\
\text { dalam } \\
\text { berinteraks } \\
\text { i secara } \\
\text { efektif } \\
\text { dengan } \\
\text { lingkungan } \\
\text { sosial dan } \\
\text { alam, serta } \\
\text { dalam } \\
\text { menempat } \\
\text { kan diri } \\
\text { sebagai } \\
\text { cerminan } \\
\text { bangsa } \\
\text { dalam } \\
\text { pergaulan } \\
\text { dunia. }\end{array}$ & $\begin{array}{l}\text { perilaku } \\
\text { mulia dari } \\
\text { Khalifah } \\
\text { Bani } \\
\text { Umayyah } \\
\text { Damaskus } \\
\text { sebagai } \\
\text { implementas } \\
\text { i dari } \\
\text { pemahaman } \\
\text { mengenai } \\
\text { dinasti Bani } \\
\text { Umayyah di } \\
\text { Damaskus. } \\
2.3 \\
\text { Menunju } \\
\text { kkan } \\
\text { sikap } \\
\text { dinamis } \\
\text { sebagai } \\
\text { implemen } \\
\text { tasi dari } \\
\text { pemaham } \\
\text { an } \\
\text { tentang } \\
\text { keberhasil } \\
\text { an Bani } \\
\text { Umayyah } \\
\text { di } \\
\text { Damasku } \\
\text { s. } \\
\text { 2.4 } \\
\text { Mencintai } \\
\text { ilmu } \\
\text { pengetahuan } \\
\text { yang } \\
\text { ditunjukkan } \\
\text { dengan } \\
\text { semangat } \\
\text { belajar yang } \\
\text { maksimal. } \\
2.5 \quad \text { Memiliki } \\
\text { sikap } \\
\text { semangat } \\
\text { mengemban } \\
\text { gkan ilmu } \\
\text { pengetahuan } \\
\text { dan } \\
\text { kerja } \\
\text { keras } \\
\text { sebagai } \\
\text { implemen } \\
\text { tasi dari } \\
\text { pemaham } \\
\text { an tentang } \\
\text { pusat- } \\
\text { pusat } \\
\text { peradaban } \\
\text { Islam pada } \\
\text { masa } \\
\text { pemerintaha } \\
\text { n } \quad \text { Bani } \\
\text { Umayyah } \\
\text { Damaskus. } \\
\text { 2.6 Menghargai } \\
\text { karya orang } \\
\text { lain sebagai } \\
\text { implementasi } \\
\text { dari } \\
\text { pemahaman } \\
\text { tentang } \\
\end{array}$ & $\begin{array}{l}\text { Umayyah } \\
\text { yang } \\
\text { Terkenal. } \\
\text { a. Prestasi } \\
\text { khalifah } \\
\text { Muawiya } \\
\text { h bin Abi } \\
\text { Sufyan. } \\
\text { b. Prestasi } \\
\text { khalifah } \\
\text { Marwan } \\
\text { bin } \\
\text { Hakam. } \\
\quad \text { Prestasi } \\
\text { khalifah } \\
\text { Walid bin } \\
\text { Abdul } \\
\text { Malik } \\
\text { d. Prestasi } \\
\text { khalifah } \\
\text { Umar bin } \\
\text { Abdul } \\
\text { Aziz. } \\
\text { Kebijakan- } \\
\text { Kebijakan } \\
\text { Pemerinta } \\
\text { han Bani } \\
\text { Umayyah } \\
1 \\
\text { Damaskus }\end{array}$ & 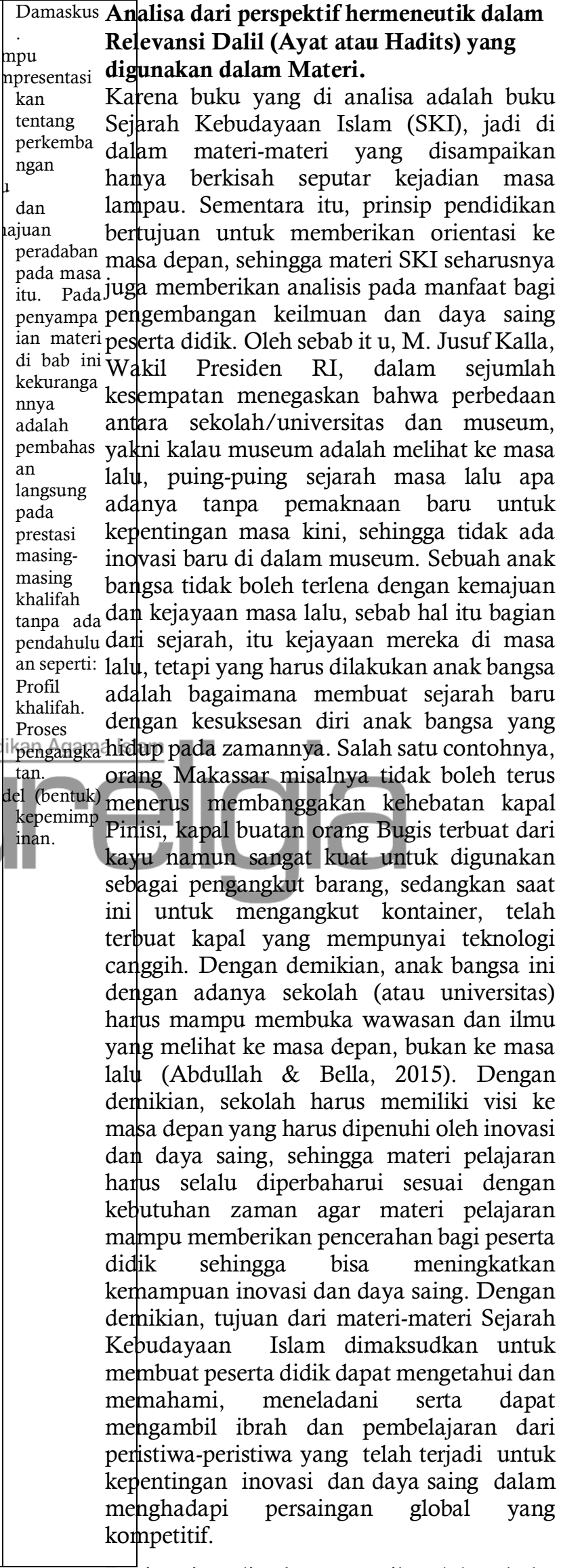 \\
\hline & & & $\begin{array}{l}\text { Dari segi analisa hermeneutika, dalam buku } \\
\text { ini yang menjadi salah satu kekurangannya } \\
\text { adalah tiap-tiap materi yang disampaikan }\end{array}$ \\
\hline
\end{tabular}


meskipun cukup mudah dipahami karena ringkas dan jelas, tidak menyertakan dalil baik berupa ayat al-Qur'an maupun hadits sebagai pendukung materi dalam setiap pembahasannya, sehingga untuk mempertajam materi analisis dan memperkuat landasan pembacaan ideal moral setiap peristiwa belum bisa dilakukan secara optimal. Dengan meminjam bahasa Khaled Abou El Fadl dalam karyanya yang berjudul Speaking in God's Name: Islamic Law, Authority, and Women, penulis dapat menerangkan bahwa jika pembahasan sejarah tidak dilakukan secara kritis, maka pembacaan terhadap peradaban masa lalu menjadi otoriter, sedangkan yang dibutuhkan untuk membaca sejarah kebudayaan Islam adalah pembacaan kritis berdasarkan dalildalil otoritatif, yakni al-Qur'an dan hadis. Oleh sebab itu, pembacaan sejarah kritis terhadap sejarah kebudayaan Islam diharapkan mampu membongkar wacana dogmatis pendidikan agama Islam, misalnya bidang sejarah kebudayaan Islam terutama masalah doktrin khilafah (negara Islam) yang dipahami kaum Muslim fundamentalis seperti Jamaah Islamiyah sebagai doktrin, sehingga dengan demikian, Pepairädigma doktrinal itu harus diubah dan harus diposisikan sebagai hasil ijtihad manusia yang relatif. Implikasinya, jika paradigma ijtihad itu diubah dalam memahami sistem khilafah itu, maka sistem khilafah itu bukan lagi diposisikan sebagai doktrin, tetapi hal itu adalah hasil ijtihad/pembacaan dari produk sejarah kebudayaan Islam masa lalu yang saat ini harus dikaji ulang dan dipahami ulang secara kritis dalam kehidupan modern dan demokratis di masa kini berdasarkan dalildalil otoritatif, yakni al-Qur'an dan hadis (E1 Fadl, 2003). Dalam pembacaan kritis ini, pluralitas pemahaman keislaman dapat terwujud yang mana hal itu sangat relevan di Negara Kesatuan Republik Indonesia (NKRI) yang sangat majemuk.

Negara Indonesia yang terbentang dari Sabang sampai Merauke dan dari Miangas sampai pulau Rote tampak berjajar pulaupulau dengan komposisi dan kontruksi yang beragam. Di pulau-pulau tersebut berdiam penduduk dengan ragam suku bangsa, bahasa, budaya, agama, adat istiadat, dan keberagaman lainnya ditinjau dari berbagai aspek. Secara keseluruhan, pulau-pulau di Indonesia berjumlah 17.508 buah pulau besar dan kecil (Sekretariat Jenderal MPR-RI, 2012).

Berdasarkan analisis tersebut, kajian ini dapat memberikan sumbangan terhadap pembangan mata pelajaran Ilmu Sejarah Kebudayaan Islam di lingkungan Madrasah Aliyah yang dapat diuraikan sebagai berikut:

a. Mata Pelajaran SKI seharusnya tidak hanya memaparkan kondisi empiris yang terjadi di masa lampau, tetapi ada pemaknaan yang aktual untuk kepentingan masa kini, misalnya di dalam pelajaran pesantren atau madrasah, ada materi ihya' al-mawat (menghidupkan tanah tak bertuan) di dalam kitab kuning hanya sekedar itu maknanya tidak dikaitkan dengan kondisi aktual saat ini untuk kepentingan pembukaan lahan sejuta hektar untuk kepentingan masyarakat, izin penggunaan lahan PTPN atau hutan lindung. Demikian juga materi Dlaman tapi tidak pernah diaktualkan dengan bank garansi.

b. Secara garis besar, mata pelajaran SKI seharusnya tidak terlalu fokus pada persoalan perang yang pernah dilakukan Nabi SAW, sahabat dan penerusnya tetapi seharusnya bisa memaknai apa rahasia di balik adanya perang itu dan ma Islaalasan apa yang melatarbelakangi perang tersebut, sehingga hal itu bisa menjadi pelajaran untuk kemajuan umat Islam, apa sekedar untuk berkuasa (penaklukan sebuah wilayah) atau ada misi dakwah. Kenapa selama masa Nabi SAW dan para sahabat peperangan atau penaklukan yang telah dilakukan itu lebih banyak berhasilnya daripada gagalnya?.

c. Mata pelajaran SKI hingga kini belum pernah memberikan ulasan yang sangat detail dan jelas, mengapa dinasti Umayyah dan Abbasiyah yang dinilai sebagai sebuah negara (dinasti) super power pada masa itu dengan segala kemajuan ilmu pengetahuan dan teknologinya yang tidak tertandingi pada saat itu hingga jatuh dan runtuh, maka pasti akan memunculkan pertanyaan besar, mengapa peradaban ilmu pengetahuan dan teknologi itu tidak mampu bangkit lagi sedahsyat yang pernah dimiliki Islam dan memenangkan persaingan peradaban pada masa sekarang, bahkan ironisnya hingga kini Timur Tengah sebagai pusat peradaban Islam yang pernah maju masihberkecamuk dalam perang saudara. Mengapa hal ini bisa terjadi? Kondisi ini harus kita pikirkan lebih lanjut, dengan mengambil sampel Jepang, tahun 1945 pernah hancur lebur 
dengan adanya bom Hiroshima dan Nagasaki sama dengan Indonesia tahun 1945 sama-sama baru mulai mengikrarkan diri merdeka, tapi kenapa kemudian Jepang lebih maju walaupun start-nya sama. Bisa jadi ini dikarenakan peradaban ilmu pentegahuan dan teknologi dari orang-orang Jepang sudah maju pada saat itu, sedangkan Indonesia pada waktu itu masih banyak yang buta huruf. Sebagai rekomendasi, harus bagaimana dan dari mana kita memulai untuk membangun peradaban Islam yang maju dan berdaya saing ke depan di Indonesia?

Mata pelajaran SKI seharusnya bisa meminjam teori Double Movement (teori gerakan ganda) dari Hans George Gadamer yang sudah pernah dipraktikkan oleh Fazlur Rahman dalam melakukan reaktualisasi nilai-nilai ajaran Islam dalam menjawab realitas modern lewat proses pemahaman teks dengan melibatkan pencipta teks tersebut. Karena itu, teori yang tepat untuk melakukan analisis sejarah adalah teori Nietzsche dimana bukan hanya menggunakan analisis sejarah monumental yang menyatakan bahwa pengetahuan merupakan alat untuk mencapai pengetahuan kebanggaan masa lalu atau bahkan kekuasaan saja. Namun demikian, tujuan mendapatkan pengetahuan pun bukan hanya sebatas untuk sekedar tahu saja, tapi lebih kepada untuk mencapai tujuan kebenaran dari pengetahuan yang relevan dengan kepentingan aktual, sehingga analisisnya bisa menggunakan analisis sejarah kritis dari Nietzsche.

Pembahasan dalam setiap bab pembahasan materi yang disampaikan disertakan seharusnya juga ada dalil (ayat al Qur'an maupun hadits) yang mendukung pembahasan materi-materi tersebut, sehingga hasil pembahasan keilmuannya bisa bersifat otoritatif, bukan otoriter. Salah wujud otentik -ala Khalid El-Fadl-dari pembacaan ijtihad terhadap sejarah kebudayaan Islam terutama masa Nabi Muhammad saw adalah gerakan dakwah yang dilakukan para walisongo dalam menyebarkan ajaran Islam di Nusantara, mereka ibarat danau yang memiliki kerohanian mendalam, pemikiran dan hati yang jernih, yang siap mengaliri dan memberikan kedamaian rohani kepada masyarakat sebagaimana dakwah Nabi Muhammad saw yang mengedepankan kedamaian dan kejernihan pikiran dan hati (Siroj, 2014). Dengan meminjam bahasa Hasan Hanafi, bagaimana sifat-sifat Allah swt
Yang Maha Pengasih dan Maha Penyayang dapat diterjemahkan dalam tata pergaulan kehidupan budaya masyarakat dan bangsa, sehingga terwujud tata kehidupan budaya yang damai, toleran, dan sejahterah (Hanafi, 2015).

\section{KESIMPULAN}

Buku Sejarah Kebudayaan Islam ini disusun dalam rangka untuk memberi kemudahan dalam mengimplementasikan Kurikulum 2013. Buku ini juga tentunya perlu pengembangan, perbaikan, pembaharuan mutakhir sesuai dengan dinamika perubahan zaman. Karena buku ini nantinya menjadi salah satu pendukung pokok peserta didik dalam proses belajar maka kualitas isi buku harusnya jadi prioritas. Isi tanpa ada ulasanulasan hikmah dan rahasia apa yang terjadi, tetapi seharusnya sudah mulai dipaparkan hikmah dan rahasia apa yang terjadi dari peristiwa itu, lebih-lebih kalau kemudian ditambah dengan relevansinya dengan pembangunan peradaban umat Islam atau bangsa yang majemuk di masa kini, sehingga materi pelajaran SKI itu tidak hanya sekadar sebagai ilmu sejarah murni tetapi juga telah memberikan sumbangan bermakna bagi pembangunan tata kehidupan peradaban umat Islam di masa kíni. Di samping itu, materi pelajaran SKI tersebut pada kenyataannya juga masih ada beberapa kesalahan dalam hal penulisan dan tata bahasa.

\section{DAFTAR PUSTAKA}

Abdullah, Husain, dan Burhanuddin Bella (eds), 74 Kumpulan Pidato Pilihan M Jusuf Kalla 2014-2015: Satu Digit, Jakarta: Buku Republika, 2016.

El Fadl, Khaled Abou, Speaking in God's Name: Islamic Law, Authority, and Women, Oxford: Oneworld Publications, 2003.

Hanafî, Hasan, Min al-Aqîdah ila al-Tsaurah, Kairo: Maktabah Madbulah, t.th.

Kalla, M Jusuf, Tinggalkan Sejarah Kejayaan, Buat Sejarah Baru, http://www.wapresri.go.id/tinggalkansejarah-kejayaan-buat-sejarah-baru/, diakses 22 Februari 2017.

Pimpinan MPR dan Tim Kerja Sosialisasi MPR Periode 2009-2014, Empat Pilar Kehidupan Berbangsa dan Bernegara, Sekretariat Jenderal MPR-RI, 2012.

Rahman, Fazlur, Islam and Modernity: Transformation of an Intellectual Tradition, Chicago dan London: The University of Chicago Press, 1984. 
Rahman, Fazlur, Islamic Methodology in History, Karachi: Central Institute of Islamic Research, 1965

Said, As'ad Ali, Al-Qaeda: Tujuan SosialPolitik, Ideologi dan Sepak Terjangnya, Jakarta: LP3ES, 2014.

Sapendi, "Internalisasi Nilai-Nilai Multikultural Dalam Pembelajaran Pendidikan Agama Islam di Sekolah: Pendidikan Tanpa Kekerasan", RAHEEMA: Jurnal Studi Gender dan Anak.

Siroj, Said Aqil, Islam Sumber Inspirasi Budaya Nusantara Menuju Masyarakat Mutamaddin, Jakarta: LTNU, 2014.

Thalib dan Bahrun, "Implementasi Pendidikan Multikultural Dalam Menciptakan Suasana Kondusif di SMA Negeri 3 Palu", ISTIQRA, Jurnal Penelitian Ilmiah, ISSN: 2338-025X Vol. 2, No. 1 Januari-Juni 2014.

Tuanaya, M. Husain, Miftachul Ula, Mariyah Ulfah (Kontributor), Buku Siswa Sejarah Kebudayaan Islam, Pendekatan Sainstifik Kurikulum 2013, Jakarta: Kementerian Agama RI, 2015.

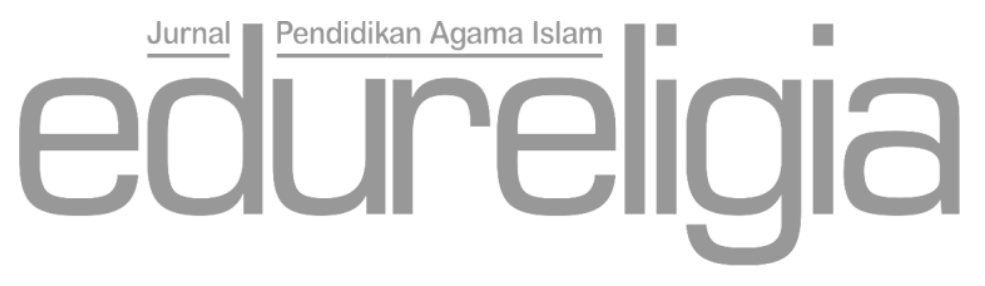

